\title{
Drivers of deep Mediterranean megabenthos communities along longitudinal and bathymetric gradients
}

\author{
Samuele Tecchio ${ }^{1, *}$, Eva Ramírez-Llodra ${ }^{1}$, Francisco Sardà1 ${ }^{1}$ Joan B. Company ${ }^{1}$, \\ Isabel Palomera ${ }^{1}$, Ariadna Mechó ${ }^{1}$, Rut Pedrosa-Pàmies ${ }^{2}$, Anna Sanchez-Vidal ${ }^{2}$ \\ ${ }^{1}$ Institut de Ciències del Mar (CSIC), 08003 Barcelona, Spain \\ ${ }^{2}$ GRC Geociències Marines, Universitat de Barcelona, 08028 Barcelona, Spain
}

\begin{abstract}
The Mediterranean deep sea, being isothermal and longitudinally trophic-graded, is an optimal natural benchmark to test for macro-ecological patterns of species distribution. The relevance of environment-biota interactions on deep-sea megafauna in the Mediterranean Sea, a matter still neglected, is addressed here along longitudinal and bathymetric axes. Benthic and nektobenthic megafauna were collected in the 3 basins of the Mediterranean: the western (Catalan Sea and southern Balearic), central (western Ionian) and eastern (south of Crete) basins, with an otter-trawl Maireta system and an Agassiz dredge between 1200 and $4000 \mathrm{~m}$ depth. Simultaneously, environmental data were collected on surface production, near-bottom physical parameters, sediment grain size and carbon content. Megafaunal biomass was higher in the Catalan Sea, decreasing eastward and with depth. Species diversity and evenness were relatively constant in the western and central Mediterranean at all depths, whereas these indices decreased with depth in the eastern Mediterranean. $\beta$-diversity analyses indicated a high species turnover between areas. The 3 basins presented significantly different environmental conditions. Sediment particulate organic carbon, surface fluorescence and sediment grain size were the 3 environmental variables that best explained the distribution of megabenthos along the longitudinal Mediterranean axis. These results show that the food supply, from either the surface or from the adjacent deepsea floor, is critical in regulating the biodiversity of deep-sea Mediterranean megafauna and that this diversity is pooled region-wide. The heterogeneity of resources may be essential in maintaining these high levels of local and regional diversity.
\end{abstract}

KEY WORDS: Deep-sea $\cdot$ Mediterranean $\cdot$ Megafauna $\cdot$ Environmental factors $\cdot$ POC $\cdot$ Biodiversity

\section{INTRODUCTION}

The regulation of benthic environments by physical and geochemical variables is, at present, a pivotal topic in the study of marine ecosystems. Global-scale studies have just begun to explore the complex interactions between environment and biota, yet are admittedly limited by the scant information available from the deep sea (Tittensor et al. 2010, Wei et al. 2010). The vast deep-sea floor remains mostly unex- plored, despite being the largest ecosystem on the planet, and it has a substantial reserve of undescribed biodiversity (Grassle \& Maciolek 1992, Ramírez-Llodra et al. 2010a). Bolstered by worldwide programs such as the Census of Marine Life, the exploration of deep-sea environments has been subject to considerable growth in the last decade (Danovaro et al. 2010).

A series of factors have been proposed as potential drivers for the composition and diversity of deep ben- 
thic communities (Levin et al. 2001, Carney 2005). Most deep-ocean ecosystems, excluding reducing systems such as hydrothermal vents or cold seeps, are heterotrophic, depending on allochthonous organic matter inputs from the surface strata (Gage \& Tyler 1991). This input of food to the deep-sea floor is, in turn, directly linked to the primary production of the sunlit layers (Billett et al. 1983, Corliss et al. 2009), river runoff, atmospheric events (Company et al. 2008), climate (Smith et al. 2009) and, to an unknown extent, human activities (Smith et al. 2008). Degradation processes in the water column, which affect organic matter availability on the bottom, have also been proposed to be influential (Soltwedel et al. 2009). In this context, it is essential to address the potential relationship between biodiversity and environmental factors to highlight the strengths and weaknesses of these ecosystems, ultimately leading to a better understanding of their functioning and of the possibilities for their management.

The Mediterranean Sea, a latitude-constrained semi-enclosed sea, presents environmental characteristics that make it of particular interest for the study of its deep benthic communities (Bethoux et al. 1999, Sardà et al. 2004a). Compared with the Atlantic Ocean, a nearly constant high temperature below $200 \mathrm{~m}$ (13 to $14^{\circ} \mathrm{C}$, depending on basin) in the Mediterranean favours enhanced degradation of food by pelagic microbes, further reducing the quantity of food available to the deep benthos (Tyler 2003). Throughout the continental slope, a strong zonation of megafauna can be found, associated with a constant reduction in abundance, biomass and diversity, accentuated under 1500 m (Pérès 1985, Company et al. 2004, D'Onghia et al. 2004). Below the 2600 and $2700 \mathrm{~m}$ isobaths, biomasses are extremely low and population densities are reduced to minimum levels (Tecchio et al. 2011).

Variations in physical conditions are known to strongly influence the response of large size classes of benthos such as macro- and megafauna; conversely, small size classes are more dependent on biotic inter-relationships (Gage \& Tyler 1991), although in recent years an effect of the environment has been observed on these biota fractions as well (Danovaro et al. 2008). These physical conditions are known to vary along the west-east axis in the Mediterranean, forming a decreasing gradient of organic matter availability at the seafloor (Azov 1991, Danovaro et al. 1999). In addition, since the start of deep-sea exploration in the Mediterranean, it has been known that although the western and central basins host varied and abundant benthic megafauna communi- ties, in the eastern basin (Levantine) all size classes of deep benthos are highly scarce in the whole continental margin (Sardà et al. 2004b and articles therein). It could thus be hypothesised that communities in the mid-slope of the western Mediterranean are structured similarly to communities in the midslope of the eastern basin. However, the relatedness of these 2 gradients (environmental and biotic) is unclear and leaves open a number of questions regarding the deep-water megafauna in the Mediterranean.

Two factors have prevented studies of this type until now: (1) the extreme difficulty in sampling unknown areas of the deep Mediterranean seafloor, especially in the central and eastern basins, results in scarcity of megabenthos datasets below $1000 \mathrm{~m}$ depth; those available are usually obtained by pooling together samples taken with different methods; and (2) the absence of integrated sampling plans to retrieve data on both the megabenthos and the abiotic environment.

During a multidisciplinary trans-Mediterranean cruise conducted in 2009, biological sampling was conducted over a large spatial scale in the Mediterranean deep sea, extending the exploration eastward to the southern Cretan Sea, and simultaneously collecting a set of environmental variables. The objective of the present study was, for the first time, to integrate the patterns of megabenthos standing stock and diversity at the species level, as well as the environmental conditions at which these communities live, along 2 axes of the Mediterranean deep-sea: depth and longitudinal.

\section{MATERIALS AND METHODS}

\section{Study areas}

The target ecosystem was the fine-mud benthos of the Mediterranean Sea on the continental slope and in the deep basins, between 1200 and $4000 \mathrm{~m}$ in depth (Fig. 1). Environmental and biological data were collected during 2 multidisciplinary oceanographic cruises in 2009, within the framework of the BIOFUN multidisciplinary project (BIOdiversity and ecosystem FUNctioning in contrasting southern European deep-sea environments: from viruses to megafauna). A 1 mo trans-Mediterranean cruise (BIOFUN I) was conducted in June 2009 aboard the RV 'Sarmiento de Gamboa', in the southern Balearic Sea in the western basin (WM), the western Ionian Sea in the central basin (CM) and the southern Cre- 


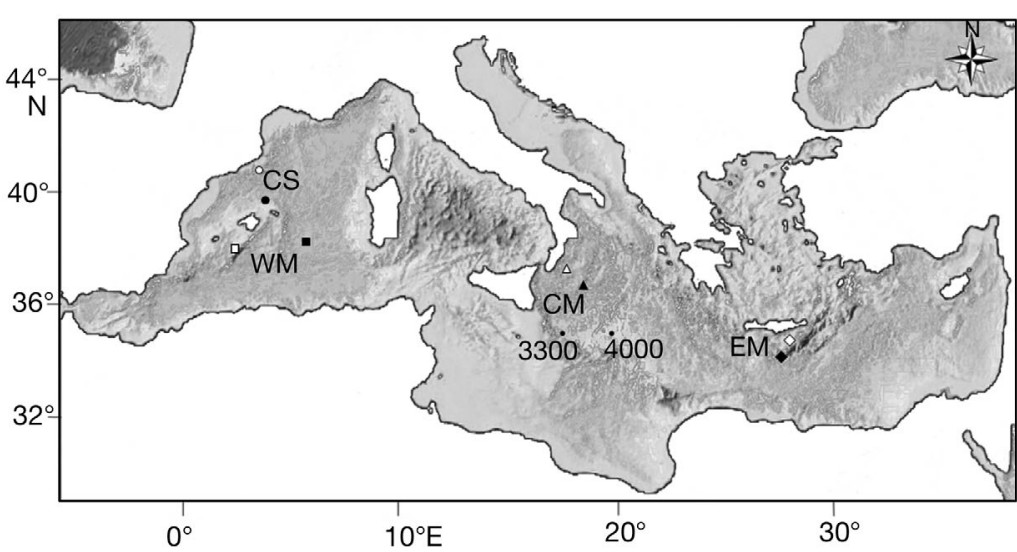

Fig. 1. Map of the Mediterranean Sea with sampling stations. $\bullet$, CS: Catalan

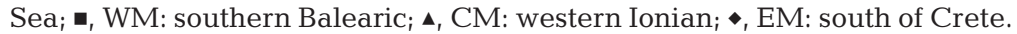
Open symbols indicate 1200 to $2000 \mathrm{~m}$ depth sampling stations; filled symbols indicate 2700 to $3000 \mathrm{~m}$ depth stations (in CM also abyssal stations at 3300 and $4000 \mathrm{~m}$ depth)

tan Sea in the eastern basin (EM). Another cruise (BIOFUN II) was conducted aboard the RV 'García del Cid' on the Catalan Sea continental slope (CS), also in the western Mediterranean, in October 2009. The sampling plan included 3 main depths in each zone: 1200,2000 and 2700 to $3000 \mathrm{~m}$. In addition, stations at 3300 and $4000 \mathrm{~m}$ depth in CM were included in the sampling plan.

\section{Environment variables}

At each station of the BIOFUN I cruise, physical water characteristics were obtained down the water column using a Seabird 9plus CTD. Data were processed using SBE data processing software v.7.18d. The variables considered were benthic temperature $\left({ }^{\circ} \mathrm{C}\right)$, benthic salinity (PSU), benthic turbidity (Formazin turbidity units, FTU) and fluorescence (relative flourescence units, RFU). As the data were collected with the same CTD and methodology throughout the cruise, the mean values of the fluorescence data in the 0 to $150 \mathrm{~m}$ depth range were used to estimate surface primary production. Turbidity near the bottom was obtained by averaging the data of the last $5 \mathrm{~m}$ of the water column.

At each station, plankton was collected using 2 nets: a standard WP2 net with a $200 \mu \mathrm{m}$ mesh for mesozooplankton and a scaled-down version for microplankton with a $53 \mu \mathrm{m}$ mesh size. Hauls were vertical from $200 \mathrm{~m}$ depth to the surface, at a speed of $1 \mathrm{~m} \mathrm{~s}^{-1}$. The filtered water volume was estimated using General Oceanics 2030R flowmeters. After sieving through 200 and $2000 \mu \mathrm{m}$ sieves for micro- and mesozooplankton, respectively, the samples were filtered on board using predried and pre-weighted 25 and $47 \mathrm{~mm}$ diameter GF/C glass microfiber filters for microplankton and mesozooplankton, respectively. The filters were then stored at $-20^{\circ} \mathrm{C}$. In the laboratory, the filters were freeze-dried for $48 \mathrm{~h}$ and weighed (with resolution of $0.0001 \mathrm{~g}$ ) to retrieve plankton biomass, which was then standardised for filtered water volume.

Sediment samples were collected using a multiple corer at the same stations. Surface sediment samples (the top $1 \mathrm{~cm}$ ) were used to investigate grain size and elemental composition. A non-homogenised fraction of approximately $1 \mathrm{~g}$ of sediment sample was treated with $10 \%$ $\mathrm{H}_{2} \mathrm{O}_{2}$ to oxidise organic matter. A Coulter Counter LS230 laser particle size analyser was used to determine grain size. The results are expressed in percentages of the coarse fraction (>63 $\mu \mathrm{m})$. Another fraction of sediment was homogenised with an agate mortar for organic carbon analysis. The samples were first decarbonated using repeated additions of $25 \% \mathrm{HCl}$ with $60^{\circ} \mathrm{C}$ drying steps in between until no effervescence was observed, and particulate organic carbon (POC) was measured on a Carlo Erba Flash 1112 elemental analyser at the Scientific Technical Services of the University of Barcelona.

\section{Megafauna sampling}

A combination of 2 samplers was used to collect the widest range of benthic megafauna: an otter-trawl Maireta system (OTMS) and an Agassiz dredge. The OTMS is a 1-warp benthic otter-trawl designed to work seamlessly on high depth grounds (Sardà et al. 1998). Its stretch mesh size at the cod-end is $40 \mathrm{~mm}$, with an outer cover of $12 \mathrm{~mm}$, to allow retrieval of small-sized fractions of megafauna. The net total length is $25 \mathrm{~m}$. Scanmar sensors were used down to $1200 \mathrm{~m}$ depth to estimate net geometry and times of arrival and departure from the bottom. The net horizontal opening was estimated at $12.7 \mathrm{~m}$ (range: 11.4 to $14.0 \mathrm{~m}$ ), and the vertical opening, at $1.4 \mathrm{~m}$, with substantially less variability. For trawls deeper than $1200 \mathrm{~m}$, the same values for the opening geometry were assumed, whereas the bottom times were calculated as the period between the end of cable paying out and the start of cable retrieval. Trawls were 
conducted at 2.6 to 2.8 knots. The Agassiz dredge had a $2.5 \mathrm{~m}$ horizontal opening and $1.2 \mathrm{~m}$ vertical opening, a net mesh size of $12 \mathrm{~mm}$, and was trawled at 2.0 knots. Haul bottom times were estimated using the same method as for the OTMS.

\section{Data analysis}

Every individual collected with the OTMS or the Agassiz dredge was identified to species level or to the lowest taxonomical level possible. A series of taxonomic literature was applied for the identification of fishes (Mercader et al. 2001, Compagno et al. 2005), crustaceans (Zariquiey 1968) and other invertebrates (Tortonese 1965, Villanueva 1992, Saiz-Salinas 1993). Species names were then cross checked with the World Register of Marine Species, available online (WoRMS, www.marinespecies.org). Individuals were then counted and weighted.

Diversity indices from abundance data were calculated sparately for the OTMS and Agassiz samples. For $\alpha$-diversity, the expected number of species, $(\mathrm{ES}(25))$, and Pielou's evenness index $\left(J^{\prime}\right)$ (Magurran 2004) were calculated. Total abundance and biomass of each species were standardised for trawled area (in $\mathrm{km}^{2}$ ) using swept area data from the Scanmar system. Multivariate ecological analyses were then performed with the PRIMER-E 6 software. The species $\times$ samples matrix was also presence/absence transformed to permit treating the OTMS and Agassiz samples as a whole. A CLUSTER analysis using the Sørensen similarity index as a resemblance measure was carried out, and a similarity profile test (SIMPROF) permutational routine (1000 restarts) was applied to test for the significance of genuine clustering. Differences in species composition between zones were tested with a single-factor similarity percentages routine (SIMPER) using Bray-Curtis similarity and were used as a $\beta$-diversity estimator (Gray 2000, Danovaro et al. 2008). A faunal list was also compiled from the presence/absence matrix.

Environmental variables were normalised, after benthic turbidity was log transformed to reduce an initial left-skewness. A 1-way ANOSIM test, using Euclidean distance as the measure and basin as the factor, was conducted on the environmental variables set. A BEST (BIOENV) routine was run to identify environmental variables correlated with differences between communities in terms of both species identities and abundances. This routine searches for the best subset of environmental variables, which optimises the match with the biotic patterns (Clarke \& Gorley 2006). To avoid the introduction of errors from possible seasonal patterns, only quantitative OTMS data from the June 2009 trans-Mediterranean cruise (BIOFUN I) were considered as response variables. BEST was run with Spearman rank as the correlation method and Euclidean distance as the resemblance measure for environmental variables. A global match test was performed, with 1000 permutations, to test for the significance of selections.

Table 1. List of otter-trawl Maireta system (OTMS) and Agassiz dredge hauls at different depths (m) and locations in 4 zones analysed during the present study, and the environmental variables used in the BEST analysis. Numbers in parentheses indicate the total number of hauls conducted, including the ones in which no sample was retrievable. POC: particulate organic carbon; DO: dissolved oxygen; FTU: Formazin turbidity units; RTU; relative flourescence units; micropl. biom.: microplankton biomass; mesozoopl.: mesozooplankton. See Fig. 1 for location of sampling sites

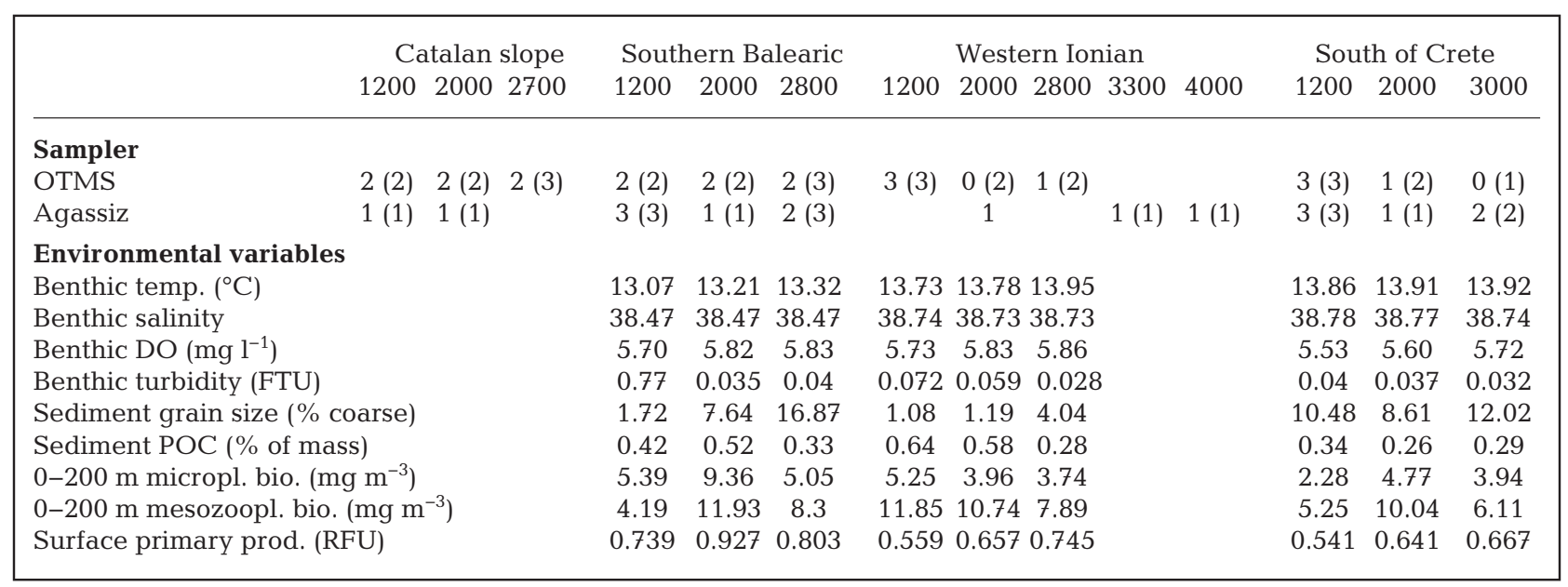




\section{RESULTS}

A total of 17 OTMS trawls and 16 Agassiz hauls were conducted successfully (Table 1). Ninety-nine species belonging to 10 different phyla were collected, and are listed in Supplement 1 at www.int-res. com/articles/suppl/m439p181_supp.pdf. Of these, one was a new species of decapod crustacean belonging to the family Galatheidae, Munidopsis ariadne, described by Macpherson (2011) and retrieved at 2000 $\mathrm{m}$ depth in the EM. Samples at $2000 \mathrm{~m}$ in the CM and at $3000 \mathrm{~m}$ in the eastern basin were not retrievable with OTMS even after repeated deployments.

The overall taxonomic composition showed that the most speciose groups were bony fishes (Actinopterygii, 40 species), decapod crustaceans ( 27 species) and molluscs (19 species, mainly Cephalopoda and Gastropoda). The abundance of the different taxonomic groups collected with the OTMS in each study area at 1200,2000 and $2700-3000 \mathrm{~m}$ is presented in Fig. 2. Bony fishes and decapod crustaceans were also the only ubiquitous groups in all areas. The areas with the least number of groups (3) were the
$2800 \mathrm{~m}$ station in the $\mathrm{CM}$ and the $2000 \mathrm{~m}$ station in the EM, followed by 4 groups at $2800 \mathrm{~m}$ depth in the $\mathrm{WM}$. The maximum number of groups (10) was found in the $\mathrm{CM}$ at $1200 \mathrm{~m}$ depth. The other areas hosted between 6 and 8 taxonomic groups.

The total biomass (Fig. 3) measured at $1200 \mathrm{~m}$ depth presented significant differences between areas (global Kruskal-Wallis test, $\mathrm{p}=0.008$ ). The CS biomass was the highest (mean \pm SE, $1258.8 \pm$ $\left.92.2 \mathrm{~kg} \mathrm{~km}^{-2}\right)$, followed by the WM $(226.0 \pm 20.2 \mathrm{~kg}$ $\left.\mathrm{km}^{-2}\right)$ and the CM $\left(235.6 \pm 26.0 \mathrm{~kg} \mathrm{~km}^{-2}\right)$. The biomass of the catches in the EM was the lowest (15.7 \pm $9.1 \mathrm{~kg} \mathrm{~km}^{-2}$ ), significantly differing from the CS biomass (Mann-Whitney test, $\mathrm{p}<0.0001$ ). At $2000 \mathrm{~m}$ depth a slight, non-significant (global Kruskal-Wallis test, $\mathrm{p}=0.301$ ) eastward decrease in biomass was evident. Biomass levels at $2800 \mathrm{~m}$ were low in all studied areas, ranging from $41.1 \pm 9.6 \mathrm{~kg} \mathrm{~km}^{-2}$ on the CS to $13.0 \mathrm{~kg} \mathrm{~km}^{-2}$ in the CM.

Diversity estimated by ES(25) on the OTMS samples showed a stable pattern with depth on the CS, ranging from 8.5 to 10.5 (Fig. 4). The same pattern was present in the WM, with values ranging between
Catalan Sea (CS)

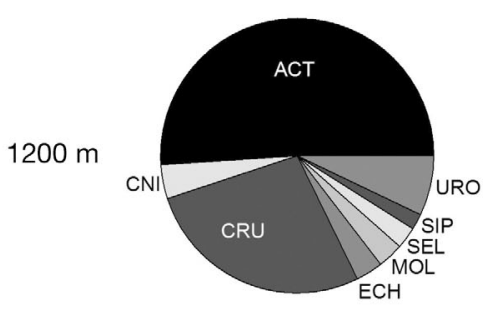

$2000 \mathrm{~m}$
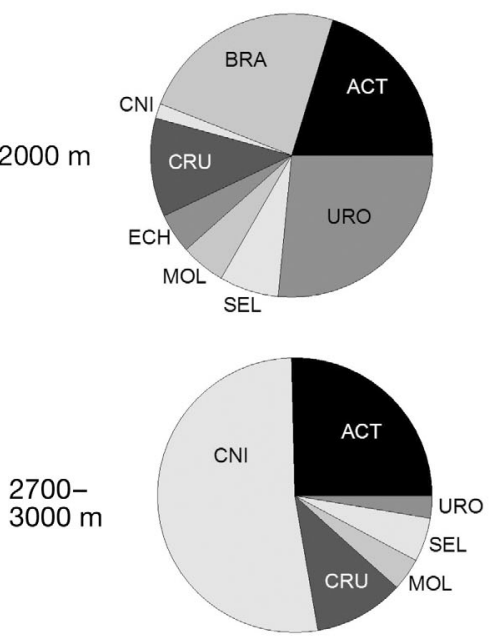

Southern Balearic (WM)
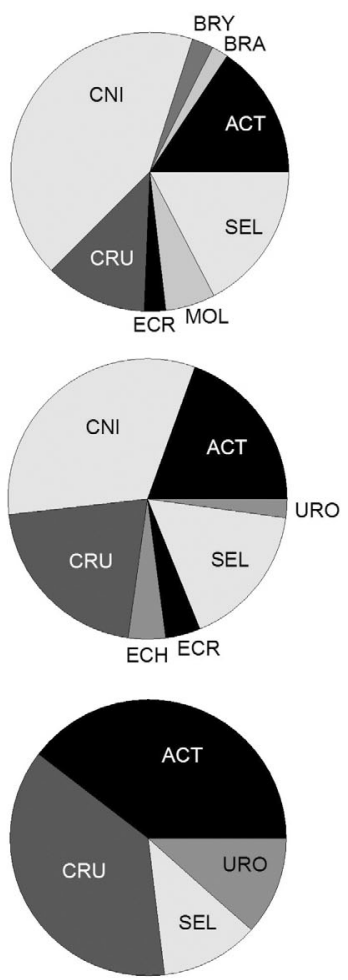

Western Ionian $(\mathrm{CM})$
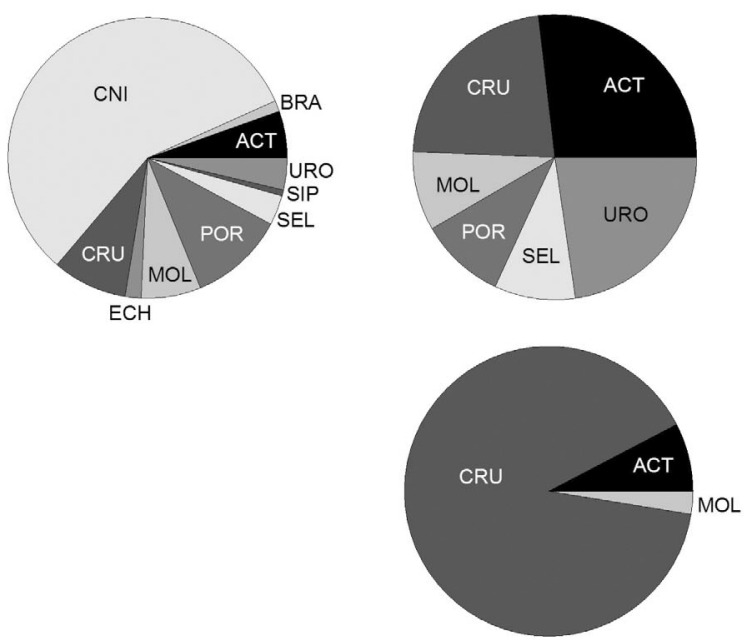

Fig. 2. Percentage of abundance for taxonomic groups in each zone and at each depth (where samples were retrieved, see Table 1). ACT: actinopterygians; BRA: brachiopods; BRY: bryozoans; CNI: cnidarians; CRU: crustaceans; ECH: echinoderms; ECR: echiurans; MOL: molluscans; POR: poriferans; SEL: selachians; SIP: sipunculans; URO: urochordata 


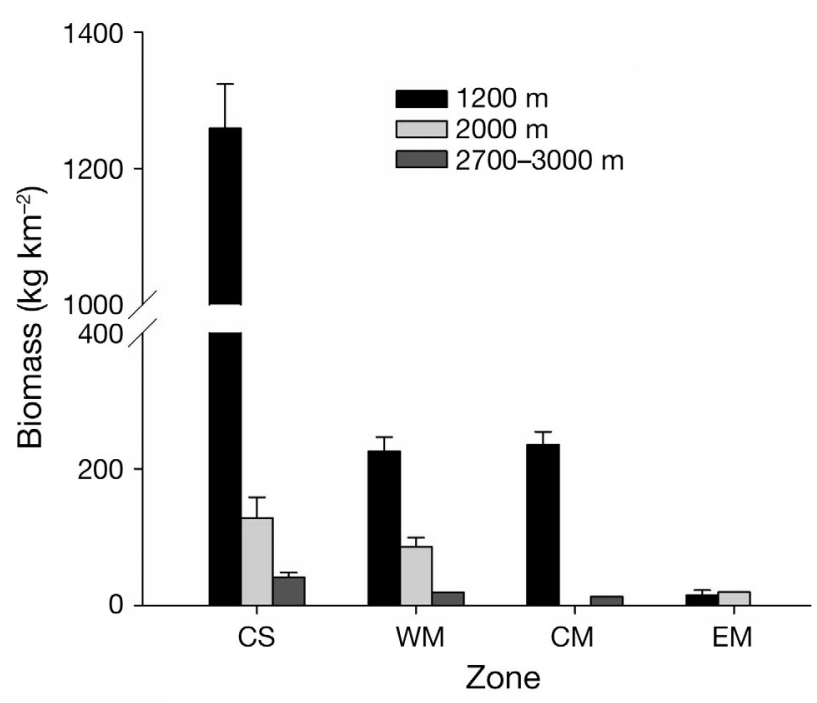

Fig. 3. Total catch biomass at different depths in the 4 zones, considering standardised biomass data from otter-trawl Maireta system samples. Values are means $( \pm$ SE). CS: Catalan Sea; WM: southern Baleatic; CM: western Ionian; EM: south of Crete

10.3 and 11.7. The CM showed a similar diversity between the $1200 \mathrm{~m}$ and the deep $2800 \mathrm{~m}$ stations, although no data were available for the $2000 \mathrm{~m}$ depth. In the EM, diversity abruptly decreased between 1200 and $2000 \mathrm{~m}$. Pielou's index of evenness ranged between 0.36 at $2000 \mathrm{~m}$ and 0.95 at $1200 \mathrm{~m}$ in the EM. In all of the other zones, Pielou's evenness was relatively constant across depths and values ranged between 0.54 and 0.86 .

Considering the Agassiz samples, ES(25) showed decreasing patterns in the 4 areas (Fig. 4). On the CS, diversity decreased from 12.2 at $1200 \mathrm{~m}$ depth to 9.1 at $2000 \mathrm{~m}$, although no replicates were available. In the WM, ES(25) decreased between 1200 and $2000 \mathrm{~m}$, but it remained constant between 2000 and $2800 \mathrm{~m}$ depth. In the CM, no samples were available at $1200 \mathrm{~m}$ depth, but diversity decreased slightly between 2000 and $3300 \mathrm{~m}$ and then remained constant down to $4000 \mathrm{~m}$ depth. In the EM, diversity decreased steeply with depth. Evenness followed comparable patterns, except in the CM, where the samples from 3300 and $4000 \mathrm{~m}$ presented higher evenness than those from the $2000 \mathrm{~m}$ station. In all 4 study areas, the sample sizes were too small to perform statistical tests to verify the significance of differences.

Ordination by CLUSTER with SIMPROF analysis of both OTMS and Agassiz hauls showed a significant grouping by depth and zone (Fig. 5). All of the $1200 \mathrm{~m}$ samples grouped together, also showing a grouping by zone, whereas at depths of from 2000 to $4000 \mathrm{~m}$ the influence of geographic area was less marked. $\beta$-diversity estimation by the SIMPER routine showed a relatively low similarity within zones (ranging from 35.9 to $46.2 \%$ ) and a high turnover diversity between zones (ranging between 61.3 and $74.5 \%$ ). The zone with the lowest internal similarity was the $\mathrm{CM}$ $(27.1 \%)$, which also included the widest depth range between samples ( $2800 \mathrm{~m}$ of depth gradient between the shallowest and deepest stations).

Table 1 shows the environmental variables collected in the present study. Significant environmental differences between basins were found by the ANOSIM test (global $\mathrm{R}=0.711, \mathrm{p}=0.001$ ). Pairwise comparisons of WM-CM and WM-EM were also significant $(p=0.0008$ in both cases), whereas the CM-EM contrast was borderline $(p=0.029)$, but still significant. Results from the BEST routine identified a group of 3 variables that together best explained the community dissimilarity along the longitudinal axis of the Mediterranean: sediment grain size, sediment POC and surface fluorescence. The results of the global match test $(\rho=0.555, p=0.004)$ corroborated the significance of that selection. Considering these 3 variables separately, the best explanatory variable was sediment POC ( $\rho=0.413)$, followed by surface fluorescence ( $\rho=0.361)$ and sediment grain size $(\rho=0.313)$. In each basin, the coarse fraction of the grain size was always highest at the deepest site (2800-3000 m depth). Sediment carbon content has more wide fluctuations between areas, with its minimum values in the eastern zone, ranging between 0.26 and $0.34 \%$. Surface fluorescence in the WM was $0.82 \pm 0.09 \mathrm{RFU}$; in the CM it was $0.65 \pm 0.09 \mathrm{RFU}$, and in the EM it was $0.62 \pm 0.07 \mathrm{RFU}$. The integrated biomass of microplankton between 0 and $200 \mathrm{~m}$ depth was $6.60 \pm 2.40 \mathrm{mg} \mathrm{m}^{-3}$ in the $\mathrm{WM}, 4.32 \pm$ $0.82 \mathrm{mg} \mathrm{m}^{-3}$ in the $\mathrm{CM}$ and $3.66 \pm 1.27 \mathrm{mg} \mathrm{m}^{-3}$ in the EM. Mesozooplankton biomass in the same depth interval was $8.14 \pm 3.87 \mathrm{mg} \mathrm{m}^{-3}$ in the $\mathrm{WM}, 10.16 \pm$ $2.04 \mathrm{mg} \mathrm{m}^{-3}$ in the $\mathrm{CM}$ and $7.13 \pm 2.55 \mathrm{mg} \mathrm{m}^{-3}$ in the EM.

\section{DISCUSSION}

Food supply is an essential factor believed to shape deep-water biodiversity. Most of the deep sea is considered to be food-limited, excluding chemosynthetically driven ecosystems or other particular conditions such as areas beneath upwelling systems or depocenters (Danovaro et al. 2003, Gage 2003). Smith et al. (2008) showed that abyssal ecosystem composition and structure are strongly modulated by the 

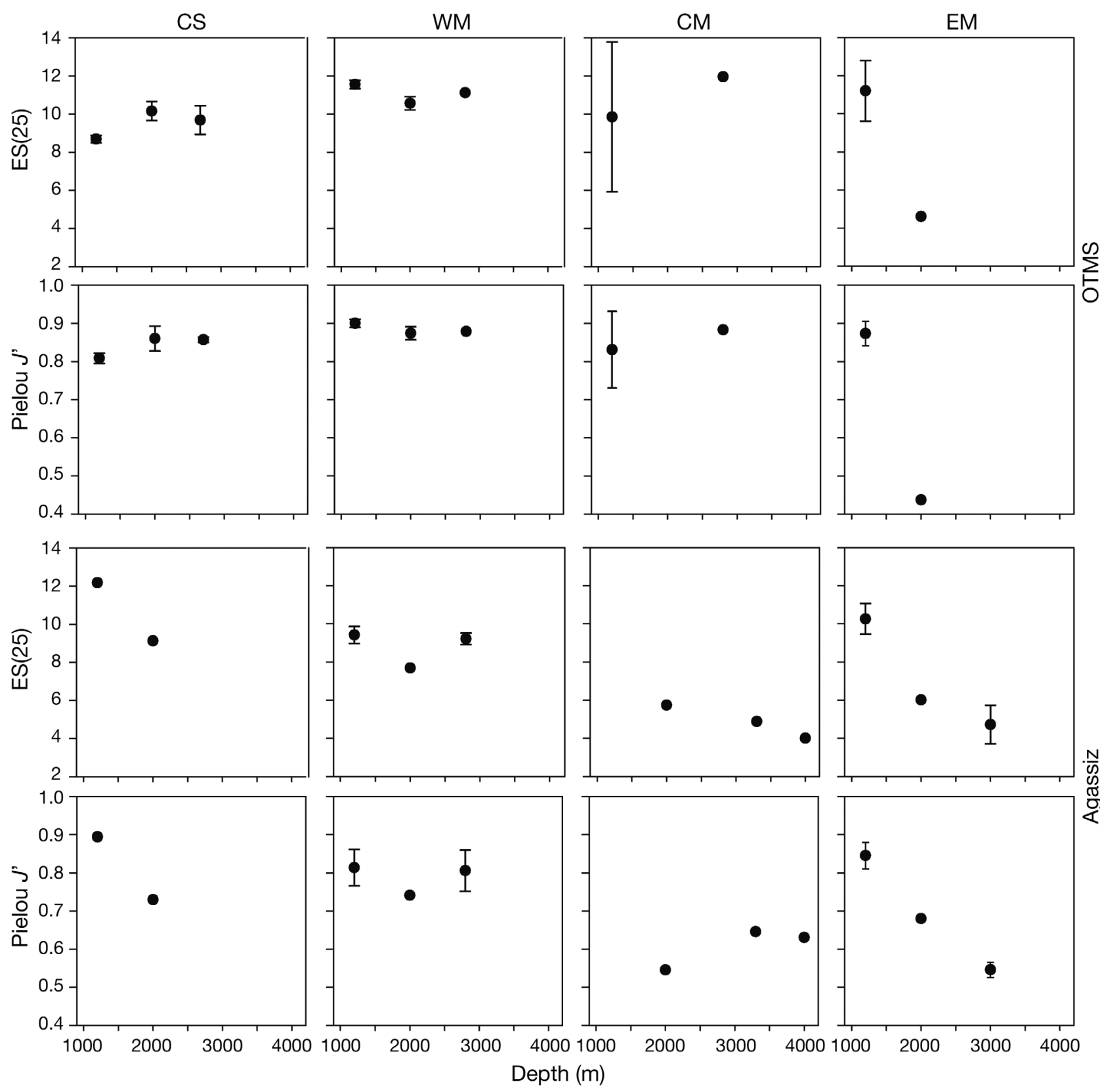

Fig. 4. Expected number of species diversity index [ES(25)] and Pielou evenness index $\left(J^{\prime}\right)$ for the otter-trawl Maireta system (OTMS) and the Agassiz dredge trawls at different depths in the 4 study areas. CS: Catalan Sea; WM: southern Balearic; CM: western Ionian; EM: south of Crete. Values are means $( \pm \mathrm{SD})$

quantity and quality of food sinking from the surface of the ocean. In addition to the food quantity limitations, the deep Mediterranean is also limited in food quality compared with the outer Atlantic Ocean, due to the enhanced degradation of the organic matter sinking in the water column (Danovaro et al. 1999). This condition has been shown to influence the abundance and diversity of benthic meiofauna (Danovaro et al. 2008, Lampadariou et al. 2009).
A marked decreasing gradient in benthic biomass was found with depth and along the west-to-east axis, with a total biomass an order of magnitude higher on the CS than at the EM site at similar depths. This bathymetric biomass decrease is in accordance with the general global pattern described by Rex et al. (2006). The most striking differences in biomass are found between the CS and the WM, both in the western Mediterranean, especially 


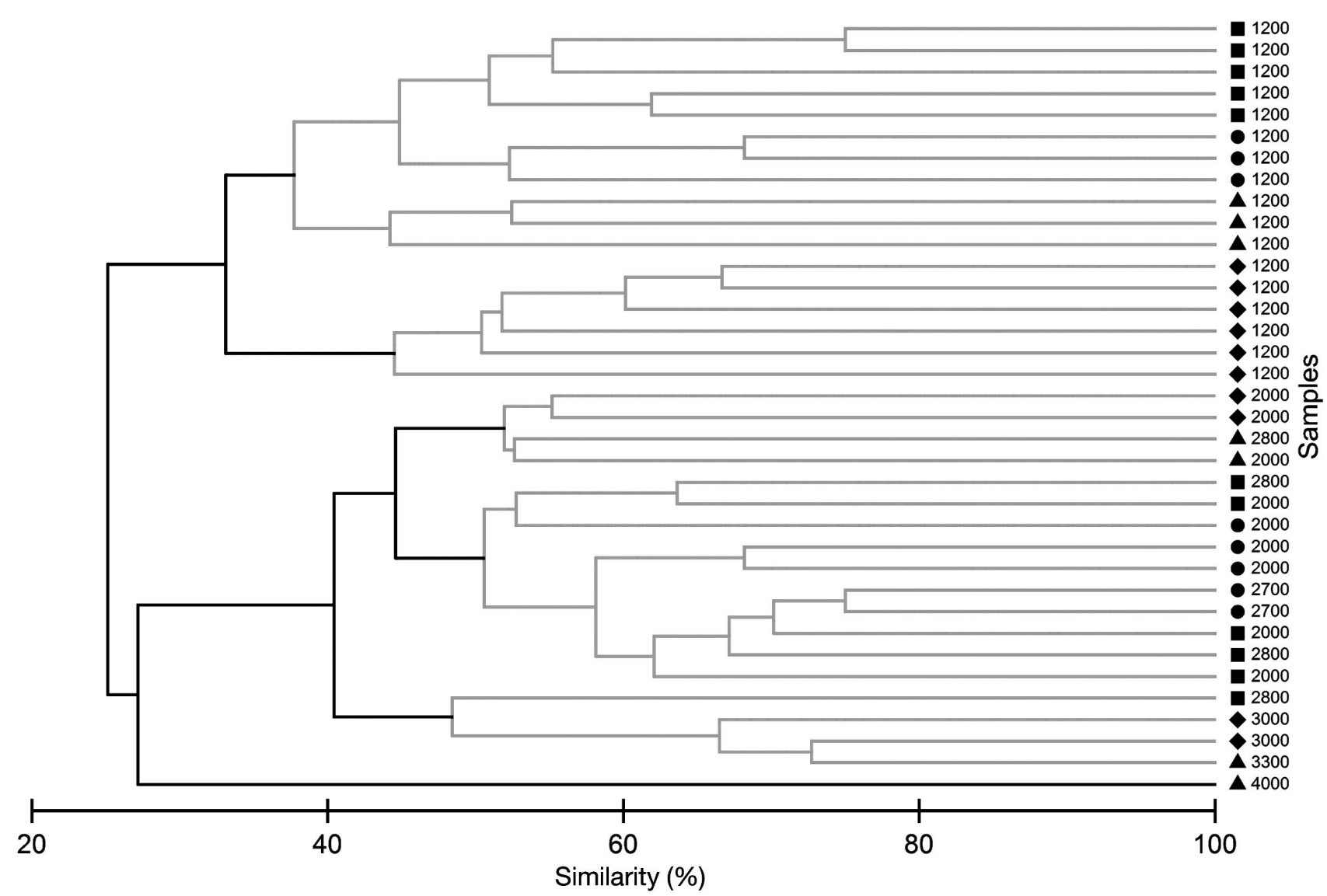

Fig. 5. CLUSTER analysis on the abundance of megabenthos from the deep Mediterranean. Numbers alongside samples indicate depth of retrieval. Grey lines indicate statistically significant groupings according to the SIMPROF routine. •: Catalan Sea; $\mathbf{\square}$ : southern Balearic; $\boldsymbol{\Delta}$ : western Ionian;

at the $1200 \mathrm{~m}$ depth. Significant differences between these 2 areas have previously been found for fish assemblages (Moranta et al. 1998).

Sediment POC, surface fluorescence (as an indicator of surface primary productivity) and sediment grain size were selected as the best descriptors of megafauna distribution in the deep Mediterranean. Primary production in the surface layers and carbon content in deep-sea sediments are known to be spatially and temporally correlated (Billett et al. 1983, Smith \& Rabouille 2002). The results presented here further confirm the longitudinal west-to-east decrease in productivity. The eastern Mediterranean basin has been traditionally considered to be one of the most oligotrophic ocean areas in the world (Azov 1991), with extreme scarcity of sinking organic matter in the water column. The variability explained by the model thus supports the concept by which surface layer dynamics modulate benthic megafaunal communities.

Relationships between sediment composition and benthic diversity have been previously described for smaller size classes of macrofauna (Etter \& Grassle 1992). For the large-sized species addressed in the present study, the biology of which is still poorly known, it is not clear how the different grain sizes of the substrate are perceived by fauna and at what scale of variability this becomes an influencing factor for their distribution and behaviour. It has been proposed that less-mobile species, such as holothurians, could be directly influenced by sediment grain size and carbon supply on the sea floor (Roberts \& Moore 1997). Finer-grained sediments, which were present in the shallower areas of the WM and CM, present higher percentages of POC (Table 1) and thus higher food availability, favouring the settlement of a more abundant and diverse infauna (Levin et al. 2001). These areas were also the most diverse in terms of species and the taxonomic composition of the megafauna. The regulation of infauna could then also influence the diversity of larger size classes of benthos as an upward trophic modulation.

Similar results were obtained in a northern Atlantic deep-sea observatory, where nutrient availability in 
the substrate was defined as the modulating agent for benthic megafauna, and the degradation processes in the water column were suggested to be influential (Soltwedel et al. 2009). In the deep Pacific Ocean, observations were also made in accordance with relating POC flux with megabenthos abundances (Smith et al. 2009). The enhanced temperatures in the Mediterranean water column, which augment organic matter degradation, could then be pivotal in determining the real extent of the benthicpelagic coupling.

It is likely that a combination of other factors is occurring and should be explored in the near future. For instance, according to these results, zooplankton biomass was not significantly correlated with the distribution of megafauna. Zooplankton biomass in oceanic areas is substantially less variable than in neritic zones, but is still considered to be a connecting factor between surface productivity and POC flux to the deep (Gage 2003). Even if slight differences can be observed in zooplankton biomass along the longitudinal axis, it is possible that their influence in the BEST analysis was masked by the gradient of primary productivity. In addition, depth has not been included as a possible explanatory variable, although CLUSTER analysis suggested strong grouping by depth strata. The rationale for our BEST analysis was to directly consider some of the variables that are known to co-vary with depth.

Of the 99 species collected, the only ubiquitous groups found in all samples were Actinopterygii and Crustacea. These groups were also the most abundant and speciose. This dominance is well established for the entirety of the deep Mediterranean (Jones et al. 2003, Company et al. 2004) and represents a major difference with the deep Atlantic sea floor (Billett et al. 2001, Soltwedel et al. 2009), which is colloquially termed the 'kingdom of the holothurians' (Kunzig 2000). Also, going from shallow to deep stations and from west to east, a reduction in the number of taxonomic groups can be appreciated. The Macrourids, a dominant actinopterygian family in both the deep Mediterranean and the Atlantic, are known to be adapted to various ranges of food availability by employing generalist and opportunistic foraging strategies (Mauchline \& Gordon 1986). The 2 dominant decapod species, Aristeus antennatus and Acantephyra eximia, can maintain high metabolic rates through their nektobenthic behaviour (Company \& Sardà 1998) and are, thus, able to live along a wide depth range while feeding in more favourable areas like the mesopelagic water column. Only fish and crustacean species seem then to be completely adapted to bathyal and abyssal conditions in the Mediterranean Sea. What remains to be confirmed is whether their presence in the deep basin is stable or just a spread effect of a shallower-based population.

At abyssal depths in the CM basin (3300 and $4000 \mathrm{~m})$, fewer species were collected than those found in a previous study in the same area (Tecchio et al. 2011). In the present study, only Agassiz samples were available for those depths, and the species collected were also all present in the bathyal sites with higher abundances. This further supports the hypothesis of deep-spreading populations. As these are the only published data on megafauna, along with those by Tecchio et al. (2011), they serve as a confirmation of species presence, providing a motivation to establish a permanent sampling station on the central Mediterranean abyssal plain.

In the present study, 2 different samplers were used simultaneously, in order to complement each other and give an integrated description of the benthic community. The OTMS was fitted with more flotation devices than usual and a roller line on the footrope to reduce the risk of the net getting caught on the bottom by collecting too much mud. The dynamic of an OTMS haul is such that nektobenthic species are positively selected (Sardà et al. 1998). In contrast, the Agassiz dredge has a smaller opening, and it maintains firm contact with the substrate, permitting the retrieval of strictly benthic species. By combining these 2 different 'sections' of the benthic domain, it was possible to compile the comprehensive faunal list presented in this work. In addition, a generally higher variability in gear behaviour was observed for the OTMS than for the Agassiz dredge; again, this is caused by the differences in gear designs and concepts. The Agassiz has proven to be usable where bottom conditions do not permit sampling with OTMS (e.g. semi-volcanic bottoms in the central Mediterranean) because they may cause the OTMS to break or be lost completely. Thus, the 2 samplers were shown to be complementary in the exploration of deep benthic megafauna. However, with the reduced number of samples retrieved, the resulting diversity patterns are far from being definitive.

The WM presented a slight, non-significant decrease in diversity along the depth axis, which is consistent with previous results with the same OTMS sampler (Tecchio et al. 2011). The Agassiz samples collected in the same area showed a clear decrease in diversity between 2000 and $2800 \mathrm{~m}$ depth. The diversity differences found in the western basin between the 2 sampled communities suggest that the dynam- 
ics of strictly benthic species may be different from those of nektobenthic megafauna. In the deep Mediterranean, the biomass of nektobenthic fauna is known to decrease below 1500 m depth (Sardà et al. 2009). Benthic invertebrates are more dependent on the organic matter found in the sediment than fishes and crustaceans, which could explain their significant decrease at the deeper station. No clear diversity patterns were found in the CM. However, the sampling difficulties experienced when studying these benthic areas resulted in a limited number of successful OTMS and Agassiz trawls, not allowing for any definitive conclusions.

In the EM, there is a clear and steep decline in species diversity from 1200 to $3000 \mathrm{~m}$ in both the OTMS and Agassiz samples. The increased oligotrophy of this basin may cause diversity to sharply decrease with depth, whereas, in the other areas, this decrease might be partially masked by the more favourable trophic conditions in the deeper layers. Moreover, the sampled zone in deeper stations may represent a patch of reduced diversity on an otherwise homogeneous sea floor. Logistics impaired the retrieval of replicates at $2000 \mathrm{~m}$, and no OTMS sample was available at $2800 \mathrm{~m}$ depth; thus, the possibility of heterogeneous habitat cannot be disregarded. In recent years, several studies have shown the importance of habitat heterogeneity in shaping deep benthic communities (Levin \& Dayton 2009, RamírezLlodra et al. 2010b, Vanreusel et al. 2010). Further studies in the bathyal and abyssal Mediterranean, including the use of imaging instruments such as remote operated vehicles or autonomous underwater vehicles, are necessary to describe in detail the deep Mediterranean expanse and to identify potential habitat characteristics that could influence heterogeneity.

$\beta$-diversity was high throughout the Mediterranean, in striking resemblance to the results from other benthic compartments such as meiofauna (Danovaro et al. 2008). This suggests that most of the deep Mediterranean biodiversity is regional rather than local and that even if basin differences are evident and have to be considered, the whole Mediterranean Sea should be considered as a wide-ranging species pool. In addition, the low overlap in composition between zones may further corroborate the hypothesis that habitat heterogeneity, along with the food supply as addressed in the present study, is a major structuring factor in deep benthic areas (Levin et al. 2001). Among other reasons, this heterogeneity could be related to different water masses at the bottom. The western and central basins of the Mediter- ranean are known to be very dynamic and affected by periodic local cascading events (Canals et al. 2006, Company et al. 2008), whereas the hydrodynamics of the deep eastern basin south of Crete are less variable, as cascading waters from the Aegean Sea are blocked by the island mass (Bethoux et al. 1999). Overall, those observations point to an effective heterogeneity of conditions, rather than to a physical heterogeneity of habitats and structures.

\section{CONCLUSIONS}

The results of the present study suggest that surface layer production differentially influences the benthic standing stock and diversity of the deep-sea Mediterranean benthos. Food supply imported from the photic zone or advected from the adjacent deepsea floor and deposited in the sediments is one of the main factors regulating the distribution of megafauna in the Mediterranean Sea over large spatial scales. With their heterogeneous distribution and composition, these food sources, with a decreasing west-east gradient in the deep Mediterranean, could be one of the key factors that determine megafaunal community structure in these habitats. In addition, the hypothesised environmentally driven bathymetric displacement of communities along the west-east axis of the Mediterranean should be reconsidered.

Two other important processes might be explored in the near future: (1) the relationship between the flow of water masses and larval drift, which may explain some of the species boundaries found in this and previous studies, and (2) the importance of small-scale physical events that may locally trigger high quantities of available organic matter at the bottom, the response to which has not yet been evaluated.

The present study was the first attempt to sample the deep megafauna along the entire longitudinal axis of the Mediterranean while simultaneously investigating possible environmental drivers. The data on deep Mediterranean megafaunal diversity are still limited, but the results obtained in this study are quite important as they present an initial basinwide picture of these deep ecosystems, providing a baseline from which to build a sound understanding of deep Mediterranean biodiversity and ecosystem functioning. This knowledge is also essential for predicting changes in the deep communities in the face of potential anthropogenic impact and, especially, climate change, and for developing sustainable management and conservation options. 
Acknowledgements. The officials and crews of RV 'García del Cid' and RV 'Sarmiento de Gamboa' are kindly acknowledged. We also thank J. López-Marco of the Polytechnic University of Catalunya (UPC) for the processing of CTD data. This work was funded through the BIOFUN project (CTM2007-28739-E) by the European Science Foundation, the PROMETEO Spanish national project (CTM2007-66316C02/MAR) by the CICYT and the European Community's Seventh Framework Programme under the HERMIONE project (Grant Agreement 226354). Geological analyses were supported by projects GRACCIE-CONSOLIDER (CSD2007-00067), REDECO (CTM2008-04973-E/MAR) and a Generalitat de Catalunya 'Grups de Recerca Consolidats' grant (2009 SGR 1305). S.T. was funded by a JAE-PRE-2008 grant, and E.R.L. was funded by a JAE-DOC-2008 grant, both from the Spanish Research Council (CSIC), Spain.

\section{LITERATURE CITED}

Azov Y (1991) Eastern Mediterranean - a marine desert? Mar Pollut Bull 23:225-232

> Bethoux JP, Gentili B, Morin P, Nicolas E, Pierre C, RuizPino D (1999) The Mediterranean Sea: a miniature ocean for climatic and environmental studies and a key for the climatic functioning of the North Atlantic. Prog Oceanogr 44:131-146

- Billett DSM, Lampitt RS, Rice AL, Mantoura RFC (1983) Seasonal sedimentation of phytoplankton to the deep-sea benthos. Nature 302:520-522

Billett DSM, Bett BJ, Rice AL, Thurston MH, Galéron J, Sibuet M, Wolff GA (2001) Long-term change in the megabenthos of the Porcupine Abyssal Plain (NE Atlantic). Prog Oceanogr 50:325-348

Canals M, Puig P, Durrieu de Madron X, Heussner S, Palanques A, Fabres J (2006) Flushing submarine canyons. Nature 444:354-357

> Carney RS (2005) Zonation of deep biota on continental margins. Oceanogr Mar Biol Annu Rev 43:211-278

Clarke KR, Gorley RN (2006) Primer v6: user manual/tutorial. PRIMER-E Ltd., Plymouth

Compagno L, Dando M, Fowler S (2005) Sharks of the world. Princeton University Press, Princeton, NJ

Company JB, Sardà F (1998) Metabolic rates and energy content of deep-sea benthic decapod crustaceans in the western Mediterranean Sea. Deep-Sea Res I 45: 1861-1880

Company JB, Maiorano P, Tselepides A, Politou C-Y, Plaity W, Rotllant G, Sardà F (2004) Deep-sea decapod crustaceans in the western and central Mediterranean Sea: preliminary aspects of species distribution, biomass and population structure. Sci Mar 68(Suppl 3):73-86

Company JB, Puig P, Sardà F, Palanques A, Latasa M, Scharek R (2008) Climate influence on deep sea populations. PLoS ONE 3:e1431

Corliss BH, Brown CW, Sun X, Showers WJ (2009) Deep-sea benthic diversity linked to seasonality of pelagic productivity. Deep-Sea Res I 56:835-841

D'Onghia G, Politou C-Y, Bozzano A, Lloris D, Rotllant G, Sion L, Mastrototaro F (2004) Deep-water fish assemblages in the Mediterranean Sea. Sci Mar 68(Suppl 3): 87-99

> Danovaro R, Dinet A, Duineveld G, Tselepides A (1999) Benthic response to particulate fluxes in different trophic environments: a comparison between the Gulf of Lions-Catalan Sea (western-Mediterranean) and the Cretan Sea (eastern-Mediterranean). Prog Oceanogr 44: 287-312

> Danovaro R, Della Croce N, Dell'Anno A, Pusceddu A (2003) A depocenter of organic matter cycling at $7800 \mathrm{~m}$ depth in the South Pacific Ocean. Deep-Sea Res I 50:1411-1420

> Danovaro R, Gambi C, Lampadariou N, Tselepides A (2008) Deep-sea nematode biodiversity in the Mediterranean basin: testing for longitudinal, bathymetric and energetic gradients. Ecography 31:231-244

Danovaro R, Company JB, Corinaldesi C, D'Onghia G and others (2010) Deep-sea biodiversity in the Mediterranean Sea: the known, the unknown, and the unknowable. PLoS ONE 5:e11832

- Etter RJ, Grassle JF (1992) Patterns of species diversity in the deep sea as a function of sediment particle size diversity. Nature 360:576-578

Gage JD (2003) Food inputs, utilization, carbon flow and energetics. In: Tyler PA (ed) Ecosystems of the world (Ecosystems of the deep ocean). Elsevier, Amsterdam

Gage JD, Tyler PA (1991) Deep-sea biology: a natural history of organisms at the deep-sea floor. Cambridge University Press, Cambridge

Grassle JF, Maciolek NJ (1992) Deep-sea species richness: regional and local diversity estimates from quantitative bottom samples. Am Nat 139:313-341

- Gray JS (2000) The measurement of marine species diversity, with an application to the benthic fauna of the Norwegian continental shelf. J Exp Mar Biol Ecol 250:23-49

> Jones EG, Tselepides A, Bagley PM, Collins MA, Priede IG (2003) Bathymetric distribution of some benthic and benthopelagic species attracted to baited cameras and traps in the deep eastern Mediterranean. Mar Ecol Prog Ser 251:75-86

Kunzig R (2000) Mapping the deep: the extraordinary story of ocean science. W. W. Norton, New York, NY

> Lampadariou N, Tselepides A, Hatziyanni E (2009) Deepsea meiofaunal and foraminiferal communities along a gradient of primary productivity in the eastern Mediterranean Sea. Sci Mar 73:337-345

Levin LA, Dayton PK (2009) Ecological theory and continental margins: where shallow meets deep. Trends Ecol Evol 24:606-617

Levin LA, Etter RJ, Rex MA, Gooday AJ and others (2001) Environmental influences on regional deep-sea species diversity. Annu Rev Ecol Evol Syst 32:51-93

> Macpherson E (2011) A new squat lobster of the genus Munidopsis (Crustacea: Decapoda: Munidopsidae) from the Mediterranean Sea. Sci Mar 75:525-532

Magurran AE (2004) Measuring biological diversity. Blackwell Science, London

> Mauchline J, Gordon JDM (1986) Foraging strategies of deep-sea fish. Mar Ecol Prog Ser 27:227-238

Mercader L, Lloris D, Rucabado J (2001) Tots els peixos del mar català: diàgnosi i claus d'identificació, Vol 128. Institut d'Estudis Catalans, Arxius de la Secció de Ciències, Barcelona

> Moranta J, Stefanescu C, Massutí E, Morales-Nin B, Lloris D (1998) Fish community structure and depth-related trends on the continental slope of the Balearic Islands (Algerian basin, western Mediterranean). Mar Ecol Prog Ser 171:247-259

Pérès JM (1985) History of the Mediterranean biota and colonization of the depths. In: Margalef R (ed) Western Mediterranean. Pergamon Press, Oxford, p 198-232 
Ramírez-Llodra E, Brandt A, Danovaro R, De Mol B and others (2010a) Deep, diverse and definitely different: unique attributes of the world's largest ecosystem. Biogeosciences 7:2851-2899

Ramírez-Llodra E, Company JB, Sardà F, Rotllant G (2010b) Megabenthic diversity patterns and community structure of the Blanes submarine canyon and adjacent slope in the northwestern Mediterranean: A human overprint? PSZNI: Mar Ecol 31:167-182

Rex MA, Etter RJ, Morris JS, Crouse J and others (2006) Global bathymetric patterns of standing stock and body size in the deep-sea benthos. Mar Ecol Prog Ser 317:1-8

Roberts D, Moore HM (1997) Tentacular diversity in deepsea deposit-feeding holothurians: implications for biodiversity in the deep sea. Biodivers Conserv 6:1487-1505

Saiz-Salinas JI (1993) Fauna Ibérica. Sipuncula. CSIC, Madrid

Sardà F, Cartes JE, Company JB, Albiol A (1998) A modified commercial trawl used to sample deep-sea megabenthos. Fish Sci 64:492-493

Sardà F, Calafat A, Flexas M, Tselepides A, Canals M, Espino M, Tursi A (2004a) An introduction to Mediterranean deep-sea biology. Sci Mar 68(Suppl 3):7-38

Sardà F, D'Onghia G, Politou CY, Tselepides A (eds) (2004b) Mediterranean deep-sea biology. Sci Mar 68(Suppl 3): 1-195

Sardà F, Company JB, Rotllant G, Coll M (2009) Biological patterns and ecological indicators for Mediterranean fish and crustaceans below 1000 m: a review. Rev Fish Biol Fish 19:329-347

Smith CR, Rabouille C (2002) What controls the mixed-layer depth in deep-sea sediments? The importance of POC flux. Limnol Oceanogr 47:418-426

Smith CR, De Leo FC, Bernardino AF, Sweetman AK, Martinez Arbizu P (2008) Abyssal food limitation, ecosystem

Editorial responsibility: Paul Snelgrove,

St John's, Newfoundland, Canada structure and climate change. Trends Ecol Evol 23: 518-528

Smith KL, Ruhl HA, Bett BJ, Billett DSM, Lampitt RS, Kaufmann RS (2009) Climate, carbon cycling, and deepocean ecosystems. Proc Natl Acad Sci USA 106: 19211-19218

> Soltwedel T, Jaeckisch N, Ritter N, Hasemann C, Bergmann M, Klages M (2009) Bathymetric patterns of megafaunal assemblages from the arctic deep-sea observatory HAUSGARTEN. Deep-Sea Res I 56:1856-1872

Tecchio S, Ramírez-Llodra E, Sardà F, Company JB (2011) Biodiversity of deep-sea demersal megafauna on western and central Mediterranean basins. Sci Mar 75: 341-350

Tittensor DP, Mora C, Jetz W, Lotze HK, Ricard D, Vanden Berghe E, Worm B (2010) Global patterns and predictors of marine biodiversity across taxa. Nature 466: 1098-1101

Tortonese E (1965) Fauna d'Italia. Echinodermata. Calderini, Bologna

Tyler PA (2003) The peripheral deep seas. In: Tyler PA (ed) Ecosystems of the world (Ecosystems of the deep ocean). Elsevier, Amsterdam

Vanreusel A, Fonseca G, Danovaro R, da Silva MC and others (2010) The contribution of deep-sea macrohabitat heterogeneity to global nematode diversity. PSZNI: Mar Ecol 31:6-20

Villanueva R (1992) Deep-sea cephalopods of the northwestern Mediterranean. J Zool (Lond) 227:267-276

Wei CL, Rowe GT, Escobar-Briones E, Boetius A and others (2010) Global patterns and predictions of seafloor biomass using random forests. PLoS ONE 5:e15323

Zariquiey R (1968) Crustáceos decápodos Ibéricos. Invest Pesq 32:1-510

Submitted: February 9, 2011; Accepted: August 1, 2011 Proofs received from author(s): October 7, 2011 